\title{
Zapošljavanje na lokalnoj razini u Republici Hrvatskoj tijekom gospodarske krize
}

JOSIP FRANIĆ Institut za javne financije

\section{SAŽETAK}

Unatoč gospodarskoj krizi i potrebi smanjenja javnih rashoda, ukupan broj zaposlenih na teret proračuna u jedinicama je lokalne i područne (regionalne) samouprave u Republici Hrvatskoj u razdoblju 2008-II. povećan za nešto više od 15\%. Osim porasta rashoda za zaposlene u apsolutnom iznosu, došlo je i do porasta njihova udjela u ukupnim rashodima lokalnih i regionalnih proračuna. Na taj se način znatan broj jedinica doveo u situaciju da im najveći dio izdataka odlazi na zaposlene te im nedostaje dovoljno sredstva za obavljanje funkcija. S obzirom da u promatranom razdoblju nije osnovana ni jedna nova jedinica, niti je bilo značajnijih pomaka u decentralizaciji koji bi zahtijevali nova radna mjesta, takav razvoj događaja može ukazivati na neodgovornu politiku zbrinjavanja nezaposlenih na teret lokalnih i regionalnih proračuna.

\section{UVOD}

Odnos prema zaposlenima na teret lokalnih i regionalnih proračuna od velike je važnosti i iznimno je osjetljivo pitanje. Pri padu proračunskih prihoda potrebno je smanjivati ukupne rashode, a najmanje je poželjno povećavati broj zaposlenih. S druge strane, smanjivanje broja zaposlenih uzrokuje dodatni porast nezaposlenosti i pogoršava socijalnu situaciju unutar zajednice, ionako narušenu krizom. Također, zbog manjka kvalificiranih ljudi - posebice u nerazvijenim i ruralnim krajevima - kasnije je vrlo teško nadomjestiti izgubljeni stručni kadar te stoga ni otpuštanje zaposlenika nije poželjno. U takvim je okolnostima uštede najbolje ostvariti skraćivanjem radnog vremena ili, u krajnjem slučaju, rezanjem plaća. Premda su neke članice Europske unije - poput Irske i Danske - pri- bjegle smanjenju broja zaposlenih na lokalnoj razini, najveće su uštede ostvarene upravo smanjenjem ili zamrzavanjem plaća i skraćivanjem radnog tjedna.

Na temelju proračunskih izvješća koja jedinice lokalne i područne (regionalne) samouprave (u daljnjem tekstu: lokalne jedinice) dostavljaju Ministarstvu financija, u ovom se radu analizira kretanje broja zaposlenih u tijelima i kod korisnika ${ }^{2}$ lokalnih i regionalnih proračuna u Hrvatskoj nakon pojave gospodarske krize 2008. Uključivanje broja zaposlenih u komunalnim društvima, ali i u drugim poduzećima u većinskom vlasništvu lokalnih jedinica pružilo bi mnogo realniji uvid, no zbog nedostupnosti detaljnijih podataka oni su izostavljeni iz analize.

\section{KONTINUIRANI PORAST ZAPOSLENIH NA LOKALNOJ RAZINI}

Unatoč potrebi smanjenja ukupnih rashoda i rashoda za zaposlene, na lokalnoj se razini u Hrvatskoj broj zaposlenih na teret lokalnih i regionalnih proračuna neprestano

I Primjerice, u Španjolskoj su plaće na lokalnoj razini smanjene za $5 \%$, u Estoniji za I5\%, a u Rumunjskoj za $25 \%$. U Latviji je radni tjedan skraćen na 4 radna dana, a u Velikoj Britaniji zamrznut je rast plaća svih zaposlenika u javnom sektoru. Za više detalja o odnosu prema zaposlenima na lokalnoj razini u Europi, vidjeti: Council of Europe, 2 OI2. 2 Zaposleni u tijelima su službenici i namještenici koji obavljaju upravne i stručne poslove iz djelokruga pojedine lokalne jedinice (primjerice u gradskom poglavarstvu), a zaposleni kod korisnika su oni u ustanovama, vijećima i fondovima kojima je osnivač lokalna jedinica, a izvor prihoda im je lokalni proračun u iznosu od 50\% ili više (vrtići, muzeji i sl.). Ukoliko to nije posebno naglašeno, prikazani podaci u tekstu odnose se na ukupan broj zaposlenih, tj. na zbroj zaposlenih u tijelima i kod korisnika. 
povećavao tijekom gospodarske krize. U razdoblju 2008II. otvoreno je 5.350 novih radnih mjesta (od toga nešto više kod korisnika nego u tijelima), što je povećanje od I5,2\% u odnosu na 2007. godinu (tablica I). broj (grafikon I). Neminovna je posljedica takvih povećanja i porast rashoda za zaposlene koji su na lokalnoj i regionalnoj razini u promatranom razdoblju ukupno porasli za gotovo milijardu kuna (tablica 2).

\section{Tablica I.}

Broj zaposlenih u tijelima i kod korisnika na lokalnoj razini (2007-II.)

\begin{tabular}{|c|c|c|c|c|c|c|c|}
\hline & & 2007. & 2008. & 2009. & 2010. & 2011. & $\begin{array}{c}\text { Povećanje/smanjenje } \\
\text { u razdoblju 2007-II. (u \%) }\end{array}$ \\
\hline \multirow{5}{*}{ u tijelima } & Županije & 1.625 & 2.070 & 2.I75 & 2.142 & 2.076 & 27,8 \\
\hline & Zagreb* $^{*}$ & 2.799 & 2.758 & 2.778 & 2.760 & $2.74 \mathrm{I}$ & $-2, \mathrm{I}$ \\
\hline & Gradovi & 5.273 & 5.754 & 6.167 & 6.IOI & 6.385 & 2I,I \\
\hline & Općine & 3.123 & 3.359 & 3.864 & 3.834 & 4.018 & 28,7 \\
\hline & Ukupno & 12.820 & I3.94I & 14.984 & 14.837 & 15.220 & 18,7 \\
\hline \multirow{5}{*}{ kod korisnika } & Županije & I.6I4 & I.897 & $2.28 \mathrm{I}$ & 2.019 & 2.158 & 33,7 \\
\hline & Zagreb & 7.613 & 7.820 & 7.826 & 7.888 & 8.000 & $5, \mathrm{I}$ \\
\hline & Gradovi & $\mathrm{I} 2.378$ & $\mathrm{I} 2.834$ & I3.049 & I3.6I2 & I3.924 & $\mathrm{I} 2,5$ \\
\hline & Općine & 886 & 999 & I.O73 & I.198 & I.359 & 53,4 \\
\hline & Ukupno & $22.49 \mathrm{I}$ & 23.550 & 24.229 & $24.7 \mathrm{I} 7$ & $25.44 \mathrm{I}$ & $\mathrm{I} 3, \mathrm{I}$ \\
\hline \multicolumn{2}{|c|}{ Ukupan broj zaposlenih } & $35.3 \mathrm{II}$ & $37.49 \mathrm{I}$ & 39.213 & 39.554 & $40.66 \mathrm{I}$ & 15,2 \\
\hline
\end{tabular}

* Zbog svog posebnog statusa grada i županije, Grad Zagreb prikazan je zasebno.

Izvor: Ministarstvo financija; izračun autora

\section{Grafikon I.}

Pregled županija, gradova i općina s obzirom na promjene ukupnog broja zaposlenih (2007-II.)

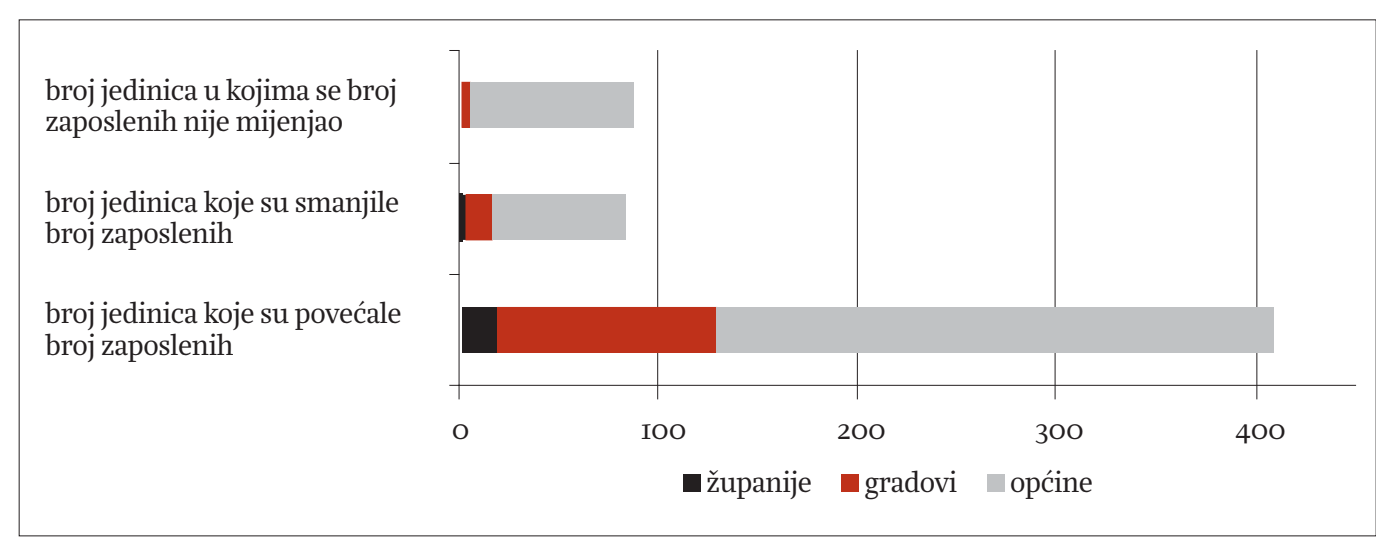

Izvor: Ministarstvo financija; izračun autora

Jedino je Grad Zagreb smanjio broj zaposlenih u tijelima (ali je zapošljavanjem kod korisnika ukupan broj zaposlenih na teret proračuna Grada Zagreba u krajnjem ishodu povećan), dok je na svim ostalim razinama (županije, gradovi i općine) došlo do povećanja, kako u tijelima tako i u korisnika, osobito tijekom 2008. i 2009. Nakon određenog usporavanja ovakvog trenda 20Io., zapošljavanje ponovno raste 2OII., S I.IO7 novih radnih mjesta u lokalnim jedinicama na razini cijele Hrvatske.

Čak 408 od ukupno 576 lokalnih jedinica povećalo je broj zaposlenih, 86 ih nije mijenjalo, dok su 82 smanjile njihov
Budući da nakon pojave krize nije osnovana ni jedna nova jedinica, niti je bilo ikakvih značajnijih pomaka u decentralizaciji koji bi zahtijevali nova radna mjesta ${ }^{3}$, ovakva situacija može ukazivati na neodgovornu politiku zbrinjavanja nezaposlenih na teret lokalnih i regionalnih proračuna bez obzira na izražene financijske poteškoće uzrokovane gospodarskom krizom. Naime, porast broja zaposlenih i rashoda za zaposlene imao je značajan utjecaj na negativna ostvarenja primarnog salda lokalne razine $u$ Hrvatskoj (grafikon 2). Primarni saldo predstavlja razliku ukupnih prihoda (prihoda poslovanja i od prodaje nefi-

3 Za više detalja o decentralizaciji u Hrvatskoj vidjeti: EIZG (20IO). 
Tablica 2.

Rashodi za zaposlene na lokalnoj razini, 2007-II. (u mil. kn)

\begin{tabular}{|c|c|c|c|c|c|c|c|}
\hline & & 2007. & 2008. & 2009 & 2010. & 2011. & $\begin{array}{c}\text { Povećanje u razdoblju } \\
2007-11 .(\mathbf{u} \%)\end{array}$ \\
\hline \multirow{5}{*}{ u tijelima } & Županije & 244,2 & 335,8 & 369,2 & $365, \mathrm{I}$ & 354,2 & 45,0 \\
\hline & Zagreb & 404,5 & 432,4 & 443,0 & 442,6 & 448,4 & IO,9 \\
\hline & Gradovi & 683,9 & 787,7 & 850,6 & $839, \mathrm{I}$ & 845,8 & 23,7 \\
\hline & Općine & 3II,I & $353, I$ & $398, \mathrm{I}$ & $4 \mathrm{IO}, 2$ & 427,7 & 37,5 \\
\hline & Ukupno & I.643,8 & I.909,I & $2.060,9$ & $2.057,0$ & $2.076, \mathrm{I}$ & 26,3 \\
\hline \multirow{5}{*}{ kod korisnika } & Županije & 103,7 & $\mathrm{I} 35,4$ & I5O,3 & $\mathrm{I} 78,8$ & 204,6 & 97,3 \\
\hline & Zagreb & 874,9 & 977,4 & I.O44,8 & I.O39,4 & I.O39,2 & $\mathrm{I} 8,8$ \\
\hline & Gradovi & I.O80,5 & I.2OI,9 & I.299,5 & I.299,O & I.3I5,9 & $2 \mathrm{I}, 8$ \\
\hline & Općine & 59,0 & 74,9 & 88,0 & 94,2 & IO4,I & 76,5 \\
\hline & Ukupno & 2.II8,I & $2.389,5$ & $2.582,6$ & $2.6 \mathrm{II}, 4$ & $2.663,9$ & 25,8 \\
\hline \multicolumn{2}{|c|}{ Ukupni rashodi za zaposlene } & $3.761,8$ & $4.298,5$ & $4.643,6$ & $4.668,4$ & $4.740,0$ & 26,0 \\
\hline
\end{tabular}

Izvor: Ministarstvo financija; izračun autora

nancijske imovine) i ukupnih rashoda (rashoda poslovanja i za nabavu nefinancijske imovine), bez iznosa kamata plaćenih na temelju ranije preuzetih obveza. Osim vlastitih prihoda, prihoda od zajedničkih poreza te pomoći iz državnog proračuna i inozemstva, Zakonom o proračunu (NN 87/o8) je općinama, gradovima, županijama i Gradu Zagrebu omogućeno ostvarivanje primitaka po osnovi zaduživanja, i to kreditima, zajmovima i izdavanjem vrijednosnih papira. Stoga je plaćanje kamata posljedica prije nastalih obveza te se njihovim isključivanjem dobiva realniji uvid u doprinos tekuće politike ukupnom saldu lokalnih jedinica.
Na grafikonu 2 je vidljivo da nakon relativno stabilnog razdoblja 2002-07., već 2008. na lokalnoj razini dolazi do financijskih poteškoća, a najveći je primarni deficit ostvaren 2009. - I,77 milijardi kuna. Te je godine više od 70\% svih lokalnih jedinica ostvarilo deficit, a ranije prikazana povećanja rashoda za zaposlene svakako su utjecala na ovako velik primarni deficit.

Niti značajni fiskalni problemi (manjak prihoda, potreba smanjivanja rashoda) nisu spriječili pojedine lokalne jedinice $u$ novim zapošljavanjima. U tablici 3 izdvojene su lokalne jedinice s najvećim proračunskim deficitima nakon

Grafikon 2.

Primarni saldo lokalne razine, 2002-II. (u mil. kn)

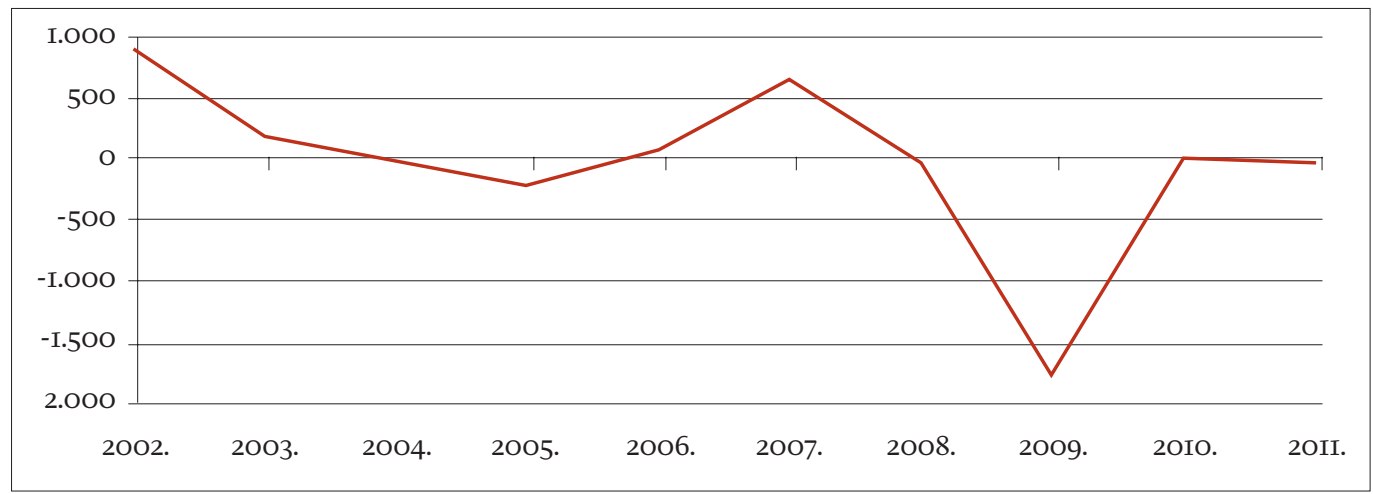

Izvor: Ministarstvo financija; izračun autora 
Tablica 3.

Županije, gradovi i općine s najvećim proračunskim deficitima nakon pojave gospodarske krize

\begin{tabular}{|c|c|c|c|c|c|c|c|c|}
\hline & & & 2007. & 2008. & 2009. & 2010. & 2011. & $\begin{array}{c}\text { Povećanje/smanjenje } \\
\text { u razdoblju 2007-II. (u \%) }\end{array}$ \\
\hline \multirow{10}{*}{ 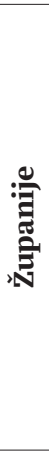 } & \multirow{3}{*}{ Ličko-senjska } & proračunski saldo (u \%) & 0,0 & $-6,0$ & $-5,3$ & $-3,5$ & $-6,8$ & - \\
\hline & & ukupan broj zaposlenih & 86 & 86 & $145^{*}$ & 83 & 85 & $-\mathrm{I}, 2$ \\
\hline & & rashodi za zaposlene (u mil. kn) & II,52 & 14,25 & $\mathrm{I} 4,6 \mathrm{I}$ & 14,33 & 14,88 & 29,2 \\
\hline & \multirow{4}{*}{ Međimurska } & proračunski saldo (u \%) & I.2 & $-\mathrm{T}$ & -83 & - I5 & -57 & - \\
\hline & & 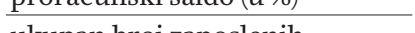 & $\frac{1,2}{6 T}$ & 1,4 & $-0,3$ & 10,9 & $\frac{0}{21}$ & - \\
\hline & & ukupan broj zaposlenın & 61 & 76 & 78 & 75 & 81 & 32,8 \\
\hline & & rashodi za zaposlene (u mil. kn) & 7,75 & $\mathrm{II}, \mathrm{I} 3$ & 12,93 & $\mathrm{I} 3, \mathrm{I} 5$ & 13,20 & 70,3 \\
\hline & \multirow{3}{*}{$\begin{array}{l}\text { Bjelovarsko- } \\
\text { bilogorska }\end{array}$} & proračunski saldo (u \%) & $-2,3$ & $-4,5$ & $-23,9$ & $-\mathrm{I} 3,5$ & 2,6 & - \\
\hline & & ukupan broj zaposlenih & 65 & I08 & I06 & 107 & 107 & 64,6 \\
\hline & & rashodi za zaposlene (u mil. kn) & 9,83 & 13,89 & 15,36 & 15,70 & 13,54 & 37,7 \\
\hline \multirow{9}{*}{ 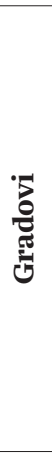 } & \multirow{3}{*}{ Županja } & proračunski saldo (u \%) & 0,9 & $-2 \mathrm{I}, 4$ & $-3,6$ & $-O, I$ & $-35,2$ & - \\
\hline & & ukupan broj zaposlenih & 87 & 86 & 88 & 94 & I42 & 63,2 \\
\hline & & rashodi za zaposlene (u mil. kn) & 7,15 & 8,07 & 8,66 & $8,9 \mathrm{I}$ & IO,II & $4 \mathrm{I}, 4$ \\
\hline & \multirow{3}{*}{ Rijeka } & proračunski saldo (u \%) & $-0,4$ & $-\mathrm{I} 2,6$ & $-5,5$ & $-15,4$ & $-16,0$ & - \\
\hline & & ukupan broj zaposlenih & I.5I6 & I.592 & I.6I6 & I.625 & I.624 & $7, \mathrm{I}$ \\
\hline & & rashodi za zaposlene (u mil. kn) & $\mathrm{I77,4I}$ & $2 \mathrm{OI}, 4 \mathrm{O}$ & 209,18 & 194,65 & 191,90 & 8,2 \\
\hline & \multirow{3}{*}{ Đakovo } & proračunski saldo (u \%) & 17,0 & 0,3 & $-22,8$ & $-\mathrm{I} 8, \mathrm{I}$ & $-\mathrm{I} 4,2$ & - \\
\hline & & ukupan broj zaposlenih & 93 & 95 & IOO & 99 & IO3 & IO, 8 \\
\hline & & rashodi za zaposlene (u mil. kn) & 6,57 & 7,38 & 8,19 & 8,49 & $8, \mathrm{I7}$ & 24,3 \\
\hline \multirow{9}{*}{ 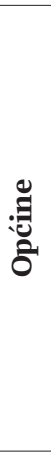 } & \multirow{3}{*}{ Dugopolje } & proračunski saldo (u \%) & $6 \mathrm{I}, 9$ & 59,5 & $-47,4$ & $-67,5$ & $-63,4$ & - \\
\hline & & ukupan broj zaposlenih & 6 & 6 & 8 & 7 & IO & 66,7 \\
\hline & & rashodi za zaposlene (u mil. kn) & $\mathrm{I}, 2 \mathrm{I}$ & $\mathrm{I}, 73$ & 1,98 & $2, \mathrm{I} 4$ & 2,26 & 85,9 \\
\hline & \multirow{3}{*}{ Poličnik } & proračunski saldo (u \%) & $-7,5$ & 0,7 & 87,8 & $-56,2$ & $-52, \mathrm{I}$ & - \\
\hline & & ukupan broj zaposlenih & I6 & $2 \mathrm{I}$ & 27 & 26 & 28 & $75, \mathrm{O}$ \\
\hline & & rashodi za zaposlene (u mil. kn) & $\mathrm{I}, 2 \mathrm{O}$ & $\mathrm{I}, 74$ & 2,27 & 2,24 & 2,30 & 92,2 \\
\hline & \multirow{3}{*}{ Pokupsko } & proračunski saldo (u \%) & $2 \mathrm{I}, 4$ & $-20,0$ & $-23,7$ & $-8,7$ & $-47,8$ & - \\
\hline & & ukupan broj zaposlenih & 6 & 6 & 6 & 5 & 5 & $-16,7$ \\
\hline & & rashodi za zaposlene (u mil. kn) & 0,65 & 0,74 & 0,80 & 0,74 & $0,7 \mathrm{I}$ & 9,6 \\
\hline
\end{tabular}

* Zbog povećanja broja zaposlenih kod korisnika s I9 na 82; već 20Io. godine kod korisnika je ponovno bilo I9 zaposlenih.

Izvor: Ministarstvo financija; izračun autora

pojave gospodarske krize. Valja napomenuti da za određena zapošljavanja vjerojatno postoje opravdani razlozi, no zasigurno su neobična tako velika povećanja broja zaposlenih i rashoda za zaposlene u vremenu sve veće krize.

Bez obzira na stalne deficite, u Međimurskoj je županiji otvoreno 20 novih radnih mjesta, a rashodi za zaposlene povećani su za 70\% tijekom promatranog razdoblja. Iako je Ličko-senjska županija 20II. imala jednog zaposlenog manje nego 2007., rashodi za zaposlene znatno su povećani. UŽupanji su rashodi za zaposlene povećani za 4I,4\%, a u općinama Dugopoljei Poličnikgotovo su udvostručeni, što je svakako pridonijelo tako velikim proračunskim deficitima.
Ipak, s obzirom na velik broj lokalnih jedinica i značajne razlike među njima, nije poželjno generalizirati podatke kad je u pitanju zapošljavanje tijekom gospodarske krize. Kao što je ranije navedeno, postoji i određen broj lokalnih jedinica koje nisu mijenjale, ili su čak smanjile broj zaposlenih. Stoga su u tablici 4 izdvojene županije, gradovi i općine s najvećim povećanjem i najvećim smanjenjem broja zaposlenih nakon 2007.

Kod županija najviše su zapošljavale Sisačko-moslavačka, Šibensko-kninska i Karlovačka. U gradu Otoku u samo tri godine broj zaposlenih narastao je s Io na 6 o (pri čemu je najveći dio radnih mjesta otvoren u gradskim tijelima). U općini Satnica Đakovačka broj zaposlenih narastao je s I 
Tablica 4.

Županije, gradovi i općine s najvećim povećanjima/smanjenjima ukupnog broja zaposlenih nakon pojave gospodarske krize

\begin{tabular}{|c|c|c|c|c|c|c|c|c|}
\hline & \multicolumn{4}{|c|}{ Najveće povećanje broja zaposlenih } & \multicolumn{4}{|c|}{ Najveće smanjenje broja zaposlenih } \\
\hline & & 2007. & 2011. & $\begin{array}{c}\text { Povećanje } \\
(\mathbf{u} \%)\end{array}$ & & 2007. & 2011. & $\begin{array}{c}\text { Smanjenje } \\
(\mathbf{u} \%)\end{array}$ \\
\hline \multirow{3}{*}{ 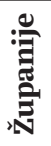 } & Sisačko-moslavačka & 68 & $22 \mathrm{I}$ & 225,0 & Varaždinska & 276 & 87 & 68,5 \\
\hline & Šibensko-kninska & 75 & $24 \mathrm{I}$ & 22I,3 & $*$ & - & - & - \\
\hline & Karlovačka & 77 & I66 & 155,6 & - & - & - & - \\
\hline \multirow{3}{*}{ } & Otok & IO & 60 & 500,0 & Hrvatska Kostajnica & 57 & 38 & 33,3 \\
\hline & Čabar & IO & 29 & I90,0 & Metković & 122 & III & 9,0 \\
\hline & Mursko Središće & I3 & 37 & I84,6 & Opuzen & 24 & 22 & 8,3 \\
\hline \multirow{3}{*}{ סُ } & Satnica Đakovačka & $\mathrm{I}$ & 16 & I.500,O & Nuštar & 23 & 6 & 73,9 \\
\hline & Podcrkavlje & 2 & I6 & 700,0 & Tordinci & 19 & 5 & 73,7 \\
\hline & Đulovac & 5 & 38 & 660,0 & Lovinac & 24 & 9 & 62,5 \\
\hline
\end{tabular}

* Osim Varaždinske, jedino je još Ličko-senjska županija smanjila broj zaposlenih u promatranom razdoblju, ali samo za jednu osobu (s 86 na 85 ). Izvor: Ministarstvo financija; izračun autora

na I6, dok je u Podcrkavlju narastao s 2 na i6 (u obje navedene općine svi zaposleni rade u općinskim tijelima). Najveća smanjenja broja zaposlenih bilježe gradovi Hrvatska Kostajnica, Metković i Opuzen, te općine Nuštar, Tordinci i Lovinac, dok je jedino Varaždinska županija značajnije smanjila broj zaposlenih (premda je i Ličko-senjska županija smanjila broj zaposlenih u promatranom razdoblju, ne radi se o značajnijem smanjenju budući je imala samo jednu zaposlenu osobu manje - vidi tablicu 3).

\section{POSLJEDIGE NEKONTROLIRANOG ZAPOŠLJAVANJA}

Povećanje rashoda za zaposlene s jedne, a potreba smanjenja ukupnih rashoda uslijed pada prihoda s druge strane, rezultirala je porastom udjela rashoda za zaposlene u proračunskim

\section{Grafikon 3.}

Kretanje ukupnih proračunskih prihoda i rashoda te rashoda za zaposlene na lokalnoj razini, 20O2-II. (u mil. kn)

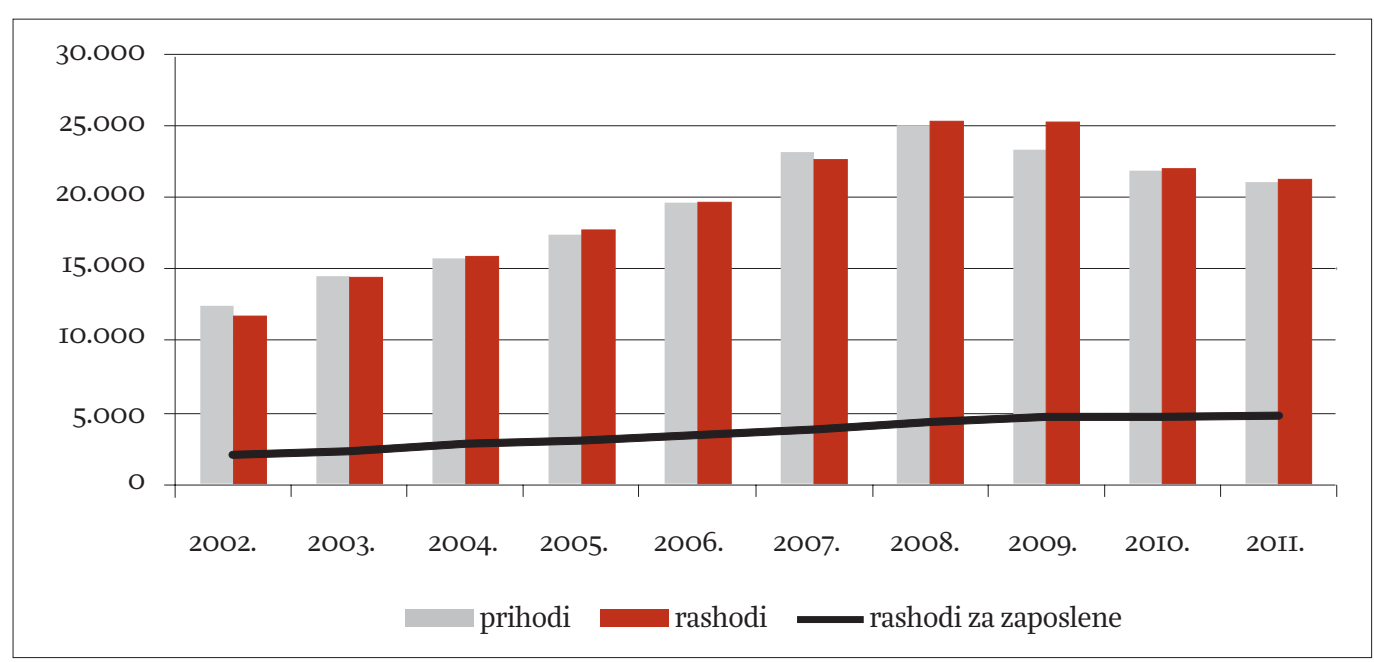

Izvor: Ministarstvo financija; izračun autora 
rashodima lokalnih jedinica. Na grafikonu 3 je prikaz kretanja ukupnih prihoda i rashoda, te rashoda za zaposlene na lokalnoj i regionalnoj razini u Hrvatskoj od 2002-II.

Rashodi za zaposlene kontinuirano rastu tijekom čitavog promatranog razdoblja, dok se ukupni rashodi smanjuju nakon 2008., što implicira da su uštede postignute na ostalim rashodovnim stavkama (u prvom redu na poslovima zaštite okoliša, poput gospodarenja otpadom i otpadnim vodama, zatim opskrbi vodom, troškovima ulične rasvjete i
Povećanja broja zaposlenih i rashoda za zaposlene u lokalnim jedinicama valja promatrati i u kontekstu njihove sposobnosti samostalnog financiranja vlastitih proračunskih rashoda. Naime, jedan od najvećih problema na lokalnoj razini u Hrvatskoj je velika ovisnost o raznim oblicima pomoći (prvenstveno iz proračuna središnje države, ali i od ostalih subjekata unutar opće države, te inozemnih vlada i međunarodnih organizacija). Svaka četvrta općina i gotovo svaki sedmi grad imaju udio pomoći u proračunskim prihodima veći od 30\%, pri čemu

\section{Grafikon 4.}

Udio rashoda za zaposlene u ukupnim proračunskim rashodima, 2007-II. (u \%)

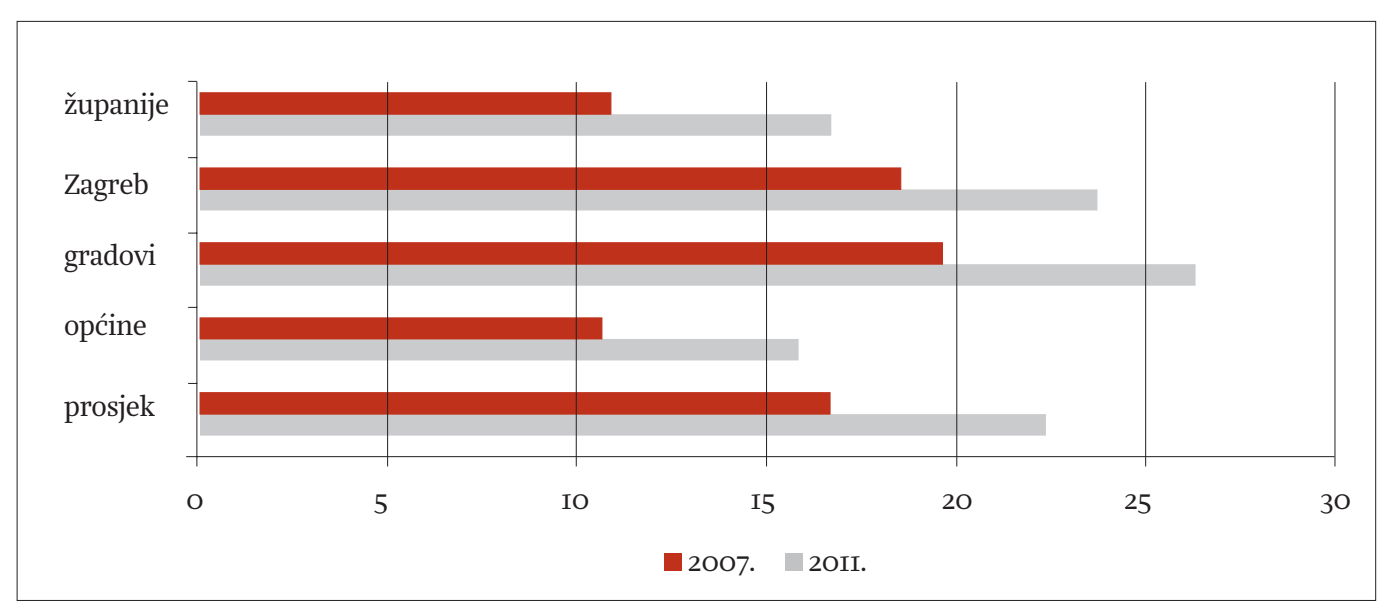

Izvor: Ministarstvo financija; izračun autora

dr.). Na taj je način udio rashoda za zaposlene u ukupnim proračunskim rashodima lokalnih jedinica u prosjeku porastao sa I6,6\% u 2007. na 22,3\% u 20II. (grafikon 4).

Tablica 5 pokazuje da je 2007. samo 5 gradova imalo udio rashoda za zaposlene iznad 30\%, a 20II. je taj broj narastao na 29, od čega ih 4 ima udio iznad 40\%. Slična situacija je i na razini općina.
3 grada i 44 općine imaju udio iznad 50\% (grafikon 5). Čak 7 županija je 2OII. više od polovice svojih ukupnih prihoda ostvarilo temeljem primljenih pomoći.

Tablica 6 daje prikaz lokalnih jedinica koje su 2oII. imale najveći udio primljenih pomoći u ukupnim prihodima. Unatoč činjenici da im obavljanje funkcija u velikoj mjeri ovisi o primljenim pomoćima, od svih je izdvojenih jedi-

\section{Tablica 5.}

Raspodjela županija, gradova i općina prema udjelu rashoda za zaposlene u proračunskim rashodima (usporedba 2007. $i$ 20II.)

\begin{tabular}{|c|c|c|c|c|c|c|c|}
\hline & & $<5 \%$ & 5-10\% & $10-20 \%$ & $20-30 \%$ & $30-40 \%$ & $>40 \%$ \\
\hline \multirow{2}{*}{ Županije } & 2007. & $\mathrm{O}$ & IO & 9 & I & $\mathrm{O}$ & $\mathrm{O}$ \\
\hline & 2 OII. & $\mathrm{O}$ & 4 & $\mathrm{I} 2$ & 4 & $\mathrm{O}$ & $\mathrm{O}$ \\
\hline \multirow{2}{*}{ Gradovi } & 2007. & $\mathrm{O}$ & I5 & 49 & 58 & 5 & $\mathrm{O}$ \\
\hline & $20 I I$. & $\mathrm{O}$ & $\mathrm{I}$ & I6 & $8 \mathrm{I}$ & 25 & 4 \\
\hline \multirow{2}{*}{ Općine } & 2007. & 40 & 156 & 190 & 35 & 7 & I \\
\hline & 2OII. & 5 & 56 & 234 & IO7 & I9 & 8 \\
\hline
\end{tabular}

Napomena: Zbog lakšeg pregleda, Zagreb je u tablici 5 i grafikonu 5 svrstan u gradove. Izvor: Ministarstvo financija; izračun autora 
Grafikon 5 .

Raspodjela županija, gradova i općina prema udjelu primljenih pomoći u ukupnim prihodima, 2OII. (u \%)

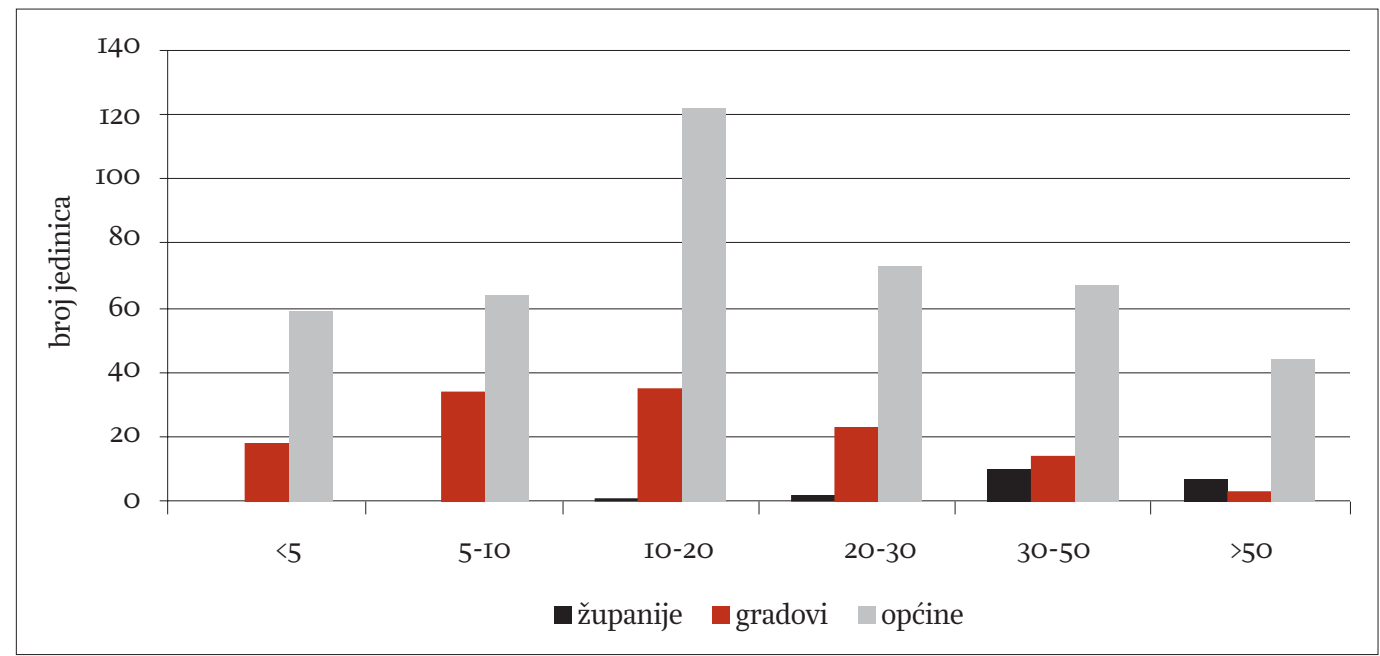

Izvor: Ministarstvo financija; izračun autora

Tablica 6.

Županije, gradovi i općine s najvećim udjelima primljenih pomoći u proračunskim prihodima (2007-II.)

\begin{tabular}{|c|c|c|c|c|c|c|c|c|}
\hline & & & 2007. & 2008. & 2009 & 2010. & $20 I I$ & $\begin{array}{c}\text { Povećanje/smanjenje } \\
\text { u razdoblju 2007-II. (u \%) }\end{array}$ \\
\hline \multirow{9}{*}{ 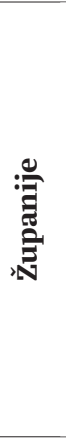 } & \multirow{3}{*}{ Požeško-slavonska } & udio pomoći u prihodima (u \%) & $2 \mathrm{I}, \mathrm{I}$ & $32, \mathrm{I}$ & 29,2 & $\mathrm{I} 8,5$ & $72, \mathrm{I}$ & - \\
\hline & & broj zaposlenih & 146 & 158 & 177 & 187 & 185 & 26,7 \\
\hline & & rashodi za zaposlene (u mil. kn) & 7,89 & 8,40 & 12,39 & 17,94 & 16,84 & II3,4 \\
\hline & \multirow{3}{*}{ Ličko-senjska } & udio pomoći u prihodima (u \%) & 69,5 & 71,2 & 72,0 & 6,4 & 69,2 & - \\
\hline & & broj zaposlenih & 86 & 86 & $\mathrm{I} 45$ & 83 & 85 & $-\mathrm{I}, 2$ \\
\hline & & rashodi za zaposlene (u mil. kn) & $\mathrm{II}, 52$ & 14,25 & I4,6I & $\mathrm{I} 4,33$ & $\mathrm{I} 4,88$ & 29,2 \\
\hline & \multirow{3}{*}{ Virovitičko-podravska } & udio pomoći u prihodima (u \%) & II,4 & $\mathrm{I} 8,2$ & 17,5 & $\mathrm{I9,7}$ & 67,3 & - \\
\hline & & broj zaposlenih & 43 & 57 & 64 & 63 & 73 & 69,7 \\
\hline & & rashodi za zaposlene (u mil. kn) & 5,43 & $8, \mathrm{I} 4$ & IO,I3 & IO,3I & 8,26 & $52, \mathrm{I}$ \\
\hline \multirow{9}{*}{ 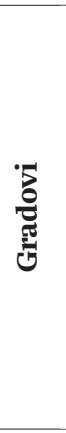 } & \multirow{3}{*}{ Vrilika } & udio pomoći u prihodima (u \%) & 46,2 & $46, I$ & 42,9 & 37,5 & 73,I & - \\
\hline & & broj zaposlenih & I3 & I3 & I3 & I3 & $\mathrm{I} 2$ & $-7,7$ \\
\hline & & rashodi za zaposlene (u mil. kn) & $\mathrm{I}, 5 \mathrm{I}$ & $\mathrm{I}, 6 \mathrm{O}$ & I,66 & $\mathrm{I}, 6 \mathrm{I}$ & 1,56 & 3,2 \\
\hline & \multirow{3}{*}{ Hrvatska Kostajnica } & udio pomoći u prihodima (u \%) & 20,7 & 29,8 & 35,9 & 28,2 & $7 \mathrm{I}, \mathrm{I}$ & - \\
\hline & & broj zaposlenih & 57 & 57 & 56 & 37 & 38 & $-33,3$ \\
\hline & & rashodi za zaposlene (u mil. kn) & 3,69 & 3,87 & 3,63 & 2,97 & 3,18 & $-\mathrm{I} 3,8$ \\
\hline & \multirow{3}{*}{ Metković } & udio pomoći u prihodima (u \%) & 25,5 & $3 \mathrm{I}, 3$ & 18,3 & 46,4 & $56, \mathrm{I}$ & - \\
\hline & & broj zaposlenih & $\mathrm{I} 22$ & I27 & I24 & II9 & III & $-9,0$ \\
\hline & & rashodi za zaposlene (u mil. kn) & 9,73 & II,39 & $\mathrm{I} 2, \mathrm{O} 7$ & II,4I & IO,48 & 7,8 \\
\hline \multirow{9}{*}{ ڤ્ } & \multirow{3}{*}{ Ervenik } & udio pomoći u prihodima (u \%) & 94,8 & 92,0 & 86,9 & 89,0 & 89,9 & - \\
\hline & & broj zaposlenih & 3 & 3 & I2 & 4 & 4 & 33,3 \\
\hline & & rashodi za zaposlene (u mil. kn) & 0,46 & 0,50 & 0,86 & 0,85 & 0,79 & 72,7 \\
\hline & \multirow{3}{*}{ Kistanje } & udio pomoći u prihodima (u \%) & 80,3 & 82,7 & 84,4 & 84,6 & $85, \mathrm{I}$ & - \\
\hline & & broj zaposlenih & IO & 9 & I2 & IO & I3 & 30,0 \\
\hline & & rashodi za zaposlene (u mil. kn) & 0,86 & $\mathrm{I}, \mathrm{I} 4$ & $\mathrm{I}, 32$ & $\mathrm{I}, \mathrm{O} 8$ & $\mathrm{I}, \mathrm{O} 7$ & 23,4 \\
\hline & \multirow{3}{*}{ Civljane } & udio pomoći u prihodima (u \%) & 9I,9 & 87,4 & 92,6 & 88,0 & $85, \mathrm{I}$ & - \\
\hline & & broj zaposlenih & 5 & 5 & 5 & 5 & 4 & $-20,0$ \\
\hline & & rashodi za zaposlene (u mil. kn) & $0,5 \mathrm{I}$ & 0,55 & 0,58 & 0,63 & 0,53 & 4,0 \\
\hline
\end{tabular}

Izvor: Ministarstvo financija; izračun autora 
nica tek Hrvatska Kostajnica provela uštede na rashodima za zaposlene nakon pojave krize, dok su ih ostale jedinice još dodatno povećale. Primjerice, općina Ervenik kojoj su primljene pomoći 20II. činile gotovo 9o \% ukupnih prihoda (u pojedinim je godinama taj udio bio još i veći), zamalo je udvostručila rashode za zaposlene. S druge strane, premda su Ličko-senjska županija, gradovi Vrlika i Metković te općina Civljane smanjili broj zaposlenih, povećali su rashode za zaposlene. To su primjeri koji jasno ukazuju na neodrživost takvog stanja i potrebu ozbiljnijih promjena na lokalnoj razini u Hrvatskoj.

\section{ZAKLJUǦAK}

Unatoč potrebi smanjenja rashoda nakon pojave gospodarske krize, velik je broj lokalnih jedinica nastavio sa zapošljavanjem na teret lokalnih proračuna, čime je ionako loša financijska situacija dodatno pogoršana. Mnoge su se jedinice dovele u situaciju da - osim financiranja plaća, doprinosa i drugih troškova zaposlenih - nemaju dovoljno sredstava za financiranje svojih funkcija (uređenja naselja i stanovanja, komunalnog gospodarstva, socijalne skrbi, zdravstva, obrazovanja, kulture, tjelesne kulture i sporta, protupožarne i civilne zaštite i dr.) te u velikoj mjeri ovise o pomoćima iz inozemstva i od subjekata unutar opće države (u prvom redu o pomoćima iz proračuna središnje države). Već i sama činjenica da 54 lokalne jedinice više od polovice svojih prihoda ostvare raznim oblicima pomoći pokazuje da nisu u stanju samostalno obavljati svoje funkcije. Ukoliko u doba gospodarske krize još i povećaju broj zaposlenih i/ili rashode za zaposlene, jasno je da njihovo daljnje postojanje nema smisla te je smanjenje ukupnog broja lokalnih jedinica nužnost. Osim što bi se smanjenjem broja takvih jedinica smanjila i izdvajanja središnje države za pomoći, omogućio bi se i efikasniji nadzor nad poslovanjem lokalne razine u Hrvatskoj, a samim time i poboljšala bi se kvaliteta javnih usluga.

\section{LITERATURA}

Audit Commission, 20Io. Surviving the crunch: Local finances in the recession and beyond. Dostupno na: [http://www.audit-commission.gov.uk/SiteCollection Documents/AuditCommissionReports/National Studies/20100323survivingthecrunch.pdf].

Bajo, A. i Jurlina-Alibegović, D., 2008. Javne financije lokalnih jedinica vlasti. Zagreb: Školska knjiga : Institut za javne financije: Ekonomski institut Zageb.

Bajo, A., 2009. "Struktura zaposlenih u lokalnim jedinicama”. Newsletter, br. 43. Dostupno na: [http://www.ijf. $\mathrm{hr} /$ newsletter/43.pdf].

\section{Council of Europe, 2012. Local Government in Critical} Times: Policies for Crisis, Recovery and a Sustainable Future. Dostupno na: [https://wcd.coe.int/com. instranet. InstraServlet?command=com.instranet.CmdBlobGet\& InstranetImage $=2056216 \&$ SecMode $=I \& D o c I d=1873672$ \&Usage $=2]$.

DZS, 20II. Priopćenja i statistička izvješća. Zagreb: Državni zavod za statistiku.

DZS, 20II. Statistički ljetopis Republike Hrvatske. Zagreb: Državni zavod za statistiku.

EIZG, 20Io. Analitičke podloge za učinkovitu decentralizaciju u Hrvatskoj. Projektna studija. Zagreb: Ekonomski institut Zagreb.

Kesner-Škreb, M., 1993. "Proračunski deficit". Financijska praksa, I7 (5), 475-477.

Ministarstvo financija Republike Hrvatske. Dostupno na:[www.mfin.hr].

Zakon o Gradu Zagrebu, NN 9o/92, 76/93, 69/95, I4/97, 36/98, 62/oI, I25/o8, 36/og. Zagreb: Narodne novine. Zakon o proračunu, NN 87/o8. Zagreb: Narodne novine. 